\title{
Flu hype and pharma failures: patients deserve better
}

\author{
Edward Davies US news and features editor, BMJ
}

New York

Epidemics, pandemics, new strains, and foreign scare stories are an annual event in the world of flu. It barely feels like winter until I've read an article about somebody thousands of miles away catching it from a farmyard animal.

We are bombarded with messages about flu whether we want them or not. And increasingly the noise is coming not from news outlets or drug manufacturers out to make a buck, but from those seeking to protect us.

In the latest article in the $B M J$ 's Too Much Medicine campaign (www.bmj.com/too-much-medicine) Peter Doshi looks at the advice on influenza vaccination from the Centers for Disease Control and Prevention.

$\mathrm{He}$ argues that both the dangers of the disease and the need to be vaccinated are being greatly oversold (doi:10.1136/bmj. f3037). The expansion of groups recommended for the vaccine in recent years, by itself, makes compelling reading, but the overall thread of his argument makes a very strong case for a rethink.
At the very least it calls into question the wisdom of the pharmacy 30 yards from my front door, which, far from unusually, offered flu vaccines 24 hours a day for the whole family right through the winter.

Patient information and patient safety are at the heart of another feature this week, in which I speak to chief medical officers from the world's largest pharmaceutical companies about their roles (doi:10.1136/bmj.f3285).

This is a fairly new breed of post, in which the holders are charged with being the voice of the patient within their company, which does at least seem a progressive step. Their status and ability to carry out this role varies hugely between firms, and, given their novelty, it's probably rather too early to gauge their success.

But if they are to mean anything a few years down the line, they must be as accountable to the public as they are to their masters, or they will be confined to the ranks of industry PR moves.

Cite this as: BMJ 2013;346:f3422

๑ BMJ Publishing Group Ltd 2013 